\title{
SPENDING REVIEW AS ESSENTIAL PART OF PUBLIC SECTOR BUDGETING: LATVIAN EXPERIENCE
}

Karlis Ketners ${ }^{1}$, Dr.oec., professor

${ }^{1}$ BA School of Business and Finance

\begin{abstract}
One of the modern trends in public sector budget governance is evaluation of allocation of the resources, re-allocation of budget resources to achieve political goals and ensure sustainable financing for different public needs. This study is the first analysis of Latvian experience of public spending reviews in 2016 2019, characterises present patterns and proposes changes for future spending reviews. In general, the Ministry of Finance is conducting public spending review as quite technocratic exercises - an opportunity to make sure that existing public institutions' budgets are being spent as efficiently as possible and conduct decision making on the civil service level. However, involvement of political level is a possibility to ensure that public spending objectives are met and the allocation of public resources reflects policy goals. The main task of the paper is to analyse the Latvian experience of regular public spending reviews and generalize recommendations for other countries and future development of the spending reviews. It can be concluded that increasing prioritisation of budgetary spending and its relation with economic development can be supported by spending reviews as a mechanism to increase government spending in priority policy areas and to ensure reallocation of resources for underfinanced budget programmes through improvement of the efficiency of expenditures. Recommendations on improvement of the spending review process and possible changes to the budget law legislation are worked out.
\end{abstract}

Key words: public finance management, spending review, budget governance, the budget law.

JEL code: $\mathrm{H} 61 ; \mathrm{H} 11$

\section{Introduction}

The state of many countries' public finances, as well as demand for sustainable and efficient public finances, has increased the interest for application of advanced innovative consolidation and budget management methods. Spending evaluation as well as reviews are among the developed budget planning and governance approaches and were conducted by countries before the 2008 - 2009 financial crisis (Canada, the Netherlands, Denmark, Finland, the United Kingdom, Australia) and introduced the approach after the crisis (Ireland, France). Generally, reviews were applied in countries which could be characterized by economic advancement and mature public management systems, but Latvia could be an example of Central and Eastern European countries which also successfully apply this method. The research aim is to examine the spending review and the budget process in Latvia. To achieve the aim, research tasks are defined - to examine legislation related to the spending reviews and to analyse the characteristics of spending reviews in Latvia conducted during 2016 - 2019 years for annual budgets. The research examined the spending review in Latvia as a process and as an evaluation of the budget expenditures. Methodology and data. The scientific literature review, analysis and synthesis, induction and deduction methods were employed to execute the research.

\section{Spending reviews as part of budget process}

As stated by Robinson (2014), since the global financial crisis in $2007-2009$, spending reviews become to be widely used by OECD governments, mainly as a tool for reducing aggregate expenditure to achieve fiscal consolidation. Based on scientific literature review (OECD, 2013) the author defines spending review as a process for systematically scrutinising expenditures to identify and implement savings measures. One of parts of the reviews is evaluation of the expenditures and re-prioritisation of the budget expenditures to ensure the fiscal space available for new spending. A

${ }^{1}$ Karlis Ketners e-mail: karlis.ketners@ba.Iv 
majority of developed countries conducts spending reviews in the last decades - Canada, New Zealand, the Netherlands, Italy, Ireland, France and the UK (Arena and Arnaboldi (2013); Ferry and Eckersley (2011); Bogacheva and Smorodinov (2018); Kennedy and Howlin (2017); Monacelli and Pennisi (2015). Based on the European Commission (2018); Robinson (2014); van Nispen (2016), it can be summarised that the spending reviews are used as an instrument to identify opportunities to improve the performance of spending programmes. The literature analysis approves that there is no single methodology for spending reviews. As stated by European Commission (2018), spending reviews fall into one of two categories : 1) strategic reviews (for assessment of the objectives of policies and programmes and evaluation of the efficiency of spending), to prioritise programmes based on policy objectives or performance; 2) efficiency reviews, which seek to identify how an existing service or programme can be delivered with fewer resources. Vandierendonck (2014) states that spending reviews can have two dimensions - 1) a strategic dimension questioning the relevance of public funding for a specific policy objective; 2) a tactical dimension aiming at increasing - for policies passing the strategic test - the efficiency of each public euro spent by optimising the relationship between expenditure level and impact, for example in terms of quality of service. There is no clear or common used definition of what a spending review is as a precise technical tool, as well as little academic research on the concept of a spending review and elements affecting performance of the reviews and spending evaluations. Researchers have been focusing on analysing the effects of introducing a spending review by a government, investigating the procedure's performance in reducing spending and helping to solve problems connected with financial sustainability (Bourgon (2009); Lapsley and Midwinter (2010); Ferry and Eckersley (2011). The OECD (2011; 2013) outlined a conceptual framework and the guidelines that regulate application of spending reviews. Catalano and Erbacci (2018) established the main notable theoretical framework for spending reviews. Mainly all mentioned researchers were focused only on medium-term spending reviews implemented after 2008 , i.e. on spending reviews implemented at times of cuts (e.g. austerity or at least challenging economic conditions) and finalised to decrease public expenditure by addressing a strategy of shortmedium term savings and cutbacks. However, the use of spending reviews could also be devoted to direct spending on new priorities - as it was before 2008, e.g. spending reviews could be (and sometimes are) also employed during better economic climates (e.g. in the UK the spending review was initially brought in during relatively good economic times by the New Labour government (Postula (2017); Emmerson (2019)). Research on performance budgeting issues (Marti, 2019) also indicates the importance of linkage between performance budgeting, budget flexibility and the implementation of medium-term expenditure frameworks. One of the primary solutions could be the integration of performance budgeting evaluation within the spending review process.

Based on Robinson (2014) it can be concluded, that there are essential differences between countries in the design and scope of the spending review process. Robinson (2018) provides classification of the reviews - selective and comprehensive spending reviews. Robinson (2018) defines a selective spending review as a spending review that is limited to several predefined review topics. For example, the government might decide that in the coming year the spending review process will look for savings options from review topics such as social assistance benefits to families, information and communications technology acquisition and management, and waste management services. Latvia, as well as Denmark (Bogachyova O. and Smorodinov O. (2019); Kraan (2011)) and the Netherlands (de Geus and Kraan (2012); van Nispen and de Jong (2017); Kabel, (2010)) are examples of countries that use the selective spending review approach, choosing review topics in 
each round of spending review. In scope of Latvian experience, pension and benefit systems, system of compensation of pharmaceuticals, information technology resources and management were analysed. Whereas Robinson (2018) also defines a comprehensive spending review, which is a spending review process that is not limited to any predefined list of review topics. In a comprehensive spending review, the Ministry of Finance and line ministries are asked to undertake an unconstrained search for the best savings options. This does not mean that in a comprehensive spending review, all programmes and business processes are reviewed-that would be impossible. Countries that have undertaken comprehensive spending reviews include the UK and Ireland. Latvian spending reviews also include negotiations with line ministries and review of expenditures to find possible savings. Based on the literature analysis and taking into consideration coverage and interventions, spending reviews can be classified into three main categories (Table 1 ).

Table 1

\section{Comparison of spending review approaches}

\begin{tabular}{|l|l|l|l|}
\hline \multicolumn{1}{|c|}{$\begin{array}{c}\text { Approaches } \\
\text { and features }\end{array}$} & \multicolumn{1}{|c|}{ Strategic review } & \multicolumn{1}{|c|}{ Technical review } & Medium-term review \\
\hline $\begin{array}{l}\text { Spending } \\
\text { review } \\
\text { function }\end{array}$ & $\begin{array}{l}\text { Centralised, comparable } \\
\text { departmental/programme } \\
\text { review }\end{array}$ & $\begin{array}{l}\text { Decentralized, single } \\
\text { internal/external review of } \\
\text { function/programme }\end{array}$ & $\begin{array}{l}\text { Centralised review of a } \\
\text { specific function within } \\
\text { ministries, e.g. real } \\
\text { estate, ICT solutions }\end{array}$ \\
\hline Coverage & Efficiency and effectiveness & Efficiency & $\begin{array}{l}\text { Efficiency and } \\
\text { performance evaluation }\end{array}$ \\
\hline $\begin{array}{l}\text { Evaluation } \\
\text { issues }\end{array}$ & $\begin{array}{l}\text { Several issues - } \\
\text { Operational/impact/ relevance } \\
\text { to the current policy }\end{array}$ & $\begin{array}{l}\text { One issue: operational } \\
\text { issue }\end{array}$ & $\begin{array}{l}\text { One issue: operational } \\
\text { issue }\end{array}$ \\
\hline $\begin{array}{l}\text { The flow of the } \\
\text { process }\end{array}$ & Bottom-up & Top-down & Top-down \\
\hline Interventions & $\begin{array}{l}\text { Efficiency gains and centralised } \\
\text { priority settings }\end{array}$ & $\begin{array}{l}\text { Efficiency gains and linear } \\
\text { cuts }\end{array}$ & $\begin{array}{l}\text { Medium-term gains and } \\
\text { initial investments }\end{array}$ \\
\hline
\end{tabular}

Source: created by the author, based on Robinson, 2018

Latvian spending review experience combines both approaches - the Cabinet of Ministers in the spring defines the scope of the spending review and this approach closes to the selective spending review; but during the process, line ministries and finance ministry undertake other measures for savings and reallocation of the resources.

\section{Organization of the spending review in Latvia}

Latvian budgetary law is represented by the Law On Budget and Financial Management (1994) Latvian law on budget and financial management (Badovskis, M. et al. (2017)), which follows international standards of a legal framework for public finance (Lienert, I. (2013)). The Law On Budget and Financial Management (1994) determines the procedures for the formulation, approval and implementation of the State Budget and local government budgets, as well as responsibility in the budget process. Financial management within the meaning of this Law applies to the funds of the State Budget and local government budgets. As an official starting point for Latvian spending reviews are amendments to the Law on Budget and Financial Management were approved by the Parliament and these amendments entered into force as of 1 January 2016. According to these amendments, the law was supplemented by the article 16. "State budget spending review". Article provisions (Law On Budget and Financial Management, 1994) state that "in order to implement the State policy more efficiently and economically, and also to regularly optimise the budget expenditure and assess its compliance with the priorities and objectives laid down in development planning documents, the Cabinet shall ensure continuous and systematic State budget spending review. The 
Cabinet shall concurrently decide on the scope of the State budget spending review and approve the schedule for the preparation of a budget. The Minister for Finance shall, within the deadline specified in the schedule for the preparation of a budget, submit to the Cabinet the results of the State budget spending review and suggestions for the use of these results in the process of developing the draft medium-term budget framework law and the draft annual State budget law." Since 2016 to ensure the interaction, evaluate possible reforms that would increase successful use of budget resources, as well as regularly assess possibilities to optimise the budget expenditure and to make proposals on these issues to the Cabinet of Ministers, the government decided to create the permanent interinstitutional Working group. The resolution of the Minister of Finance approved the working group and its task is to make proposals for the spending review priorities. In 2016, a comprehensive spending review was carried out, which included assessment of all expenditure of the ministries. The civil servants, considering their knowledge of the public administration processes and finance, did the initial expenditure evaluation. Since 2019, the parliamentary secretary of the Ministry of Finance Atis Zakatistovs chairs the working group, thereby ensuring the political involvement in the spending review process. Also, in 2019 for the first time, spending ministry ministers participated in the working group, discussing the sector funding policy revision possibilities.

Spending Review is an integral part of the preparation of the State budget and consists of the following elements.

- Scope: The Cabinet of Ministers approves proposals for changes in the State budget policy areas and expenditure.

- Staff: According to the scope experts of the Ministry of Finance together with line ministries carries out a spending review of State budget.

- Platform: inter-institutional working group holds discussions on the spending review ideas and results.

- Results and decisions: The Cabinet of Ministers meets the results of Spending Review Report and decides on the implementation of the results.

- Accountability and public access: Results of the Spending Review Report are available at the website of Ministry of Finance.

Given that spending review over the years has become an integral part of medium-term budget development process as well as has proven to be an effective tool from which results provides financial resources for the sector priorities not only annually but also for the medium-term, in the middle of 2018 in the Ministry of Finance there was created a Budget Development Division, which directly is responsible for the spending review.

The Budget Development Division was established with the aim to strengthen analytical capacity. The Budget Development Division has experts with strong analytical skills and experience in public administration. One of the main preconditions in the spending review process is close cooperation with the line ministries. To strengthen this cooperation, within the spending review process, the Budget Development Division organizes various levels of negotiations with line ministries discussing the effectiveness of spending and effective achievement of results.

The Budget Development Division is part of the Budget Policy Development Department and its main tasks are:

1) to organize the annual state budget spending review process and to ensure that its results are included in the budget development process (prepare proposals for the scope of the state budget spending review; prepare information, guidelines and give consultations for the organization of 
the spending review process; and to summarize and analyse the results of the spending review and to make proposals for its further use in the budget development process);

2) to systematically analyse the state budget expenditure and prepare relevant analytical information, make proposals for changes in the state budget expenditure policy and ensure their implementation;

3) to ensure the accumulation of information on results and performance indicators.
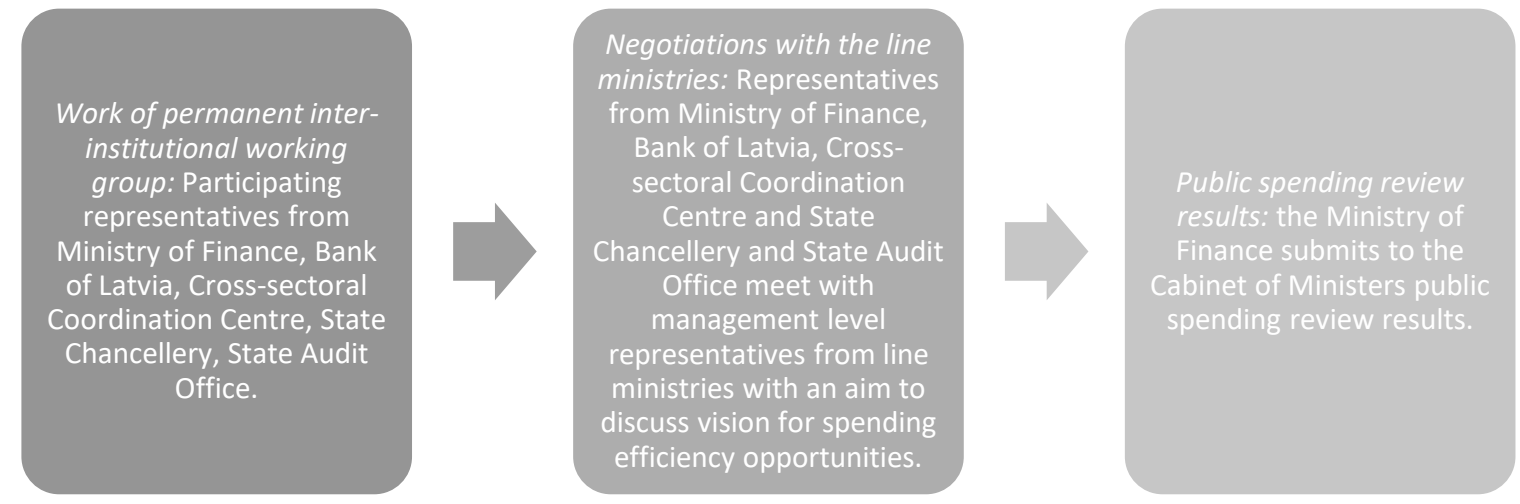

Source: author's created based on the Ministry of Finance, 2020

Fig. 1. The main stages of the spending review process

The central part of the spending review process is an intra-departmental working group which is formed by Minister of Finance involving staff of the budget sector of the Ministry as well as experts from Bank of Latvia, State Chancellery, Cross-sectoral Coordination Centre and State Audit Office (as an observer). Responsible stakeholders and their primary areas of involvement are as follows.

- Bank of Latvia - provides macroeconomic analysis- chosen because it collects and processes statistical data, as well as develops, compiles, analyses and disseminates statistical information. One of the working areas of the Bank is research. Experts of the Bank has provided macroeconomic analysis for different areas. Also, together with their experts, an analysis was done on a zero-based budgeting approach for the reimbursed pharmaceutical products and state library management.

- Cross-sectoral Coordination Centre (CSCC) - provides a view on the linkage between budget expenditure and policy objectives and results - chosen because it is the leading institution in national development planning and coordination in Latvia. CSCC is responsible for the National Development Plan of Latvia and the Sustainable Development Strategy. Besides, CSCC does sector policy cross-sectoral supervision and develops proposals for state development and implementation. In cooperation with the CSCC within the spending review process, a permanent accounting model for the allocation of the state budget expenditure was created, improved objectives, results and performance indicators for the state budget programs and sub-programs.

- State Chancellery - provides expertise and proposals for investment efficiency and productivity analysis - chosen because it ensures public administration, human resource and public sector remuneration policy development, coordinates and supervises its implementation. Within the spending review, State Chancellery has developed and implemented permanent invested funding and implemented sector policy efficiency and economy methodology of analysis.

- State Audit Office - participates as an observer - taking into account that the State Audit Office is an independent collegial supreme audit institution and is a critical element of the State's financial control system serving the public interest by providing independent assurance on the effective and useful utilization of central and local government resources it performs as an 
observer in the spending review working group. For the spending review, State Audit Office contributes to the working group with its audit results on different issues. For example, compliance audits within financial audits, aimed at verifying that transactions that correspond to the financial statements comply with legislation, planning documents and national (international) practice. Within the budget process, spending review is included in the decision-making schedule (Fig. 2)

Source: Ministry of Finance, 2020

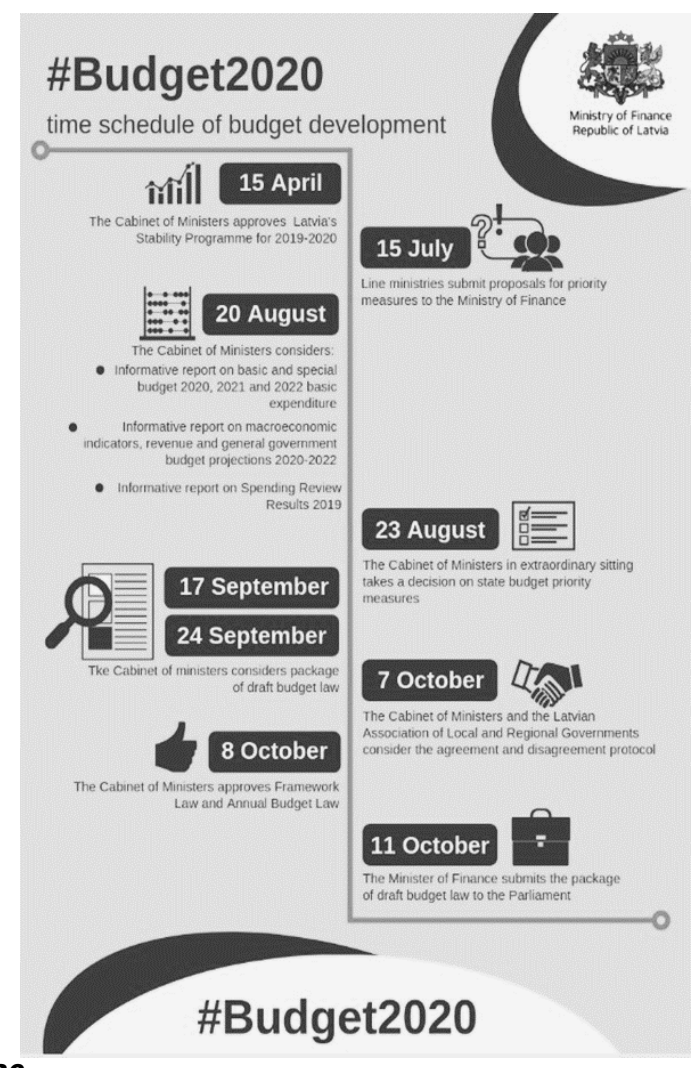

Fig. 2. Example of the schedule of the spending review process

\section{Spending review as the instrument for ensuring proper expenditure prioritisation}

For the spending Review 2016, on 1 March 2016 the Cabinet of Ministers approved the scope of spending review (effects of budget elasticity tools; correlation to market prices; irrational spending changes compared to 2015; analysis of past new policy initiatives etc.). Reviewing priorities were defined as main spending sectors - health and education sectors (also two working groups were set up for the overall process, one of the dedicated explicitly to health spending). Also, fundamental review and update performance information linking it to policies and budget programme expenditures were done. As a part of the process, improvement to develop tools for efficiency and effectiveness analysis of expenditure (linking expenditure with policy outcomes and outputs). Within 2016 spending Review, expenditure non-performance was tackled, through analysis of Regular surplus in budget programmes from 2013 to 2015, aligning costs with direct performance results. The Review also presented possibilities to make determined policy changes in legislation that affect revenue and expenditure, e.g. redistributions from new policy initiatives (made redistributions from new policy initiatives over the last three years (from 2013 to 2015)), analysis of legislation regarding fixed-term measures, the update of expenditure in line with updated GDP forecasts. As technical review expenditure redistributions from one budget programme to another (from 2013 to 2015) and revenue non-performance (disregard of specific toll revenue) were done. As medium-term measures, horizontal review of the expenditures on heating and fuel was done with medium-term expenditure 
trend compared to market prices. As the result of the review, in fiscal terms efficiency gains of EUR 61,3 million for 2017 were achieved, which provided additional funds for reprioritising expenditures both within line ministries and also for general government priorities as EUR 32,6 million were re-allocated for government priorities and EUR 28,7 million were identified as internal ministerial resources.

Spending Review 2017 consisted of two main parts. As strategic review changes in sector policy funding through an update of developed proposals, assessment of the progress of implementation, and implementation of 'zero-based' budgeting - pilot projects for Ministry of Health and Ministry of Culture, together with the expertise of Bank of Latvia. As changes in state budget policy, a new procedure for funding allocation to priority sector measures was established, which is an update of procedures for accountability of base expenditures in line with budget management improvements. As a technical review, a review of long-term vacant posts, analysis of support functions and horizontal measures for priorities, identification of potential internal resources was done. As a part of the comprehensive spending review, also sectoral proposals for function optimization, other additional proposals were considered. During the process, a review of lowest priority administrative expenditure was done, which is a- revised lower priority administrative expenditure for the period 2015-2019 such as business trip and work travel expenses, communication services, office goods. As for medium-term review, a review of priority measures from previous periods was conducted. In order to find additional funds for the financing of current priority actions for the years 2018, 2019 and 2020, a review has been carried out of the pre-allocated funding for priority measures, assessing the relevance, results achieved and effectiveness of the priority measures. In fiscal terms, efficiency gains of EUR 81,1 million for 2018 were achieved, which provided additional funds for reprioritising expenditures both within line ministries and also for general government priorities as EUR 28,6 million were allocated for government priorities, and EUR 52,5 million were identified as internal ministerial resources.

Spending Review 2018 was approved on 12 March 2018 by the Cabinet of Ministers covering changes in the state budget policy (legislative amendments for work efficiency, more extensive use of automatic data processing systems, analytical work strengthening) and changes in line ministry policy funding with a focus on effective real estate use and management and information and communication technologies optimization. During the review, horizontal solutions to make public budget resources more efficient were taken: a review of the funding pre-allocated for priorities and other activities, assessing the relevance, results achieved and effectiveness of the priority measures; revised press (newspapers, magazines) subscription costs in both electronic and printed formats; analysis of the share of December's monthly expenditure against total annual expenditure. In the field of information and communication technologies: evaluating resource sharing capabilities for information systems functionality in the field of information and communication technologies in order to promote improvements in the effectiveness of public administration ICT support. Optimisation proposals and their implementation pathways have been developed to improve ICT governance in public administrations. As technical review, proposals from ministries and other proposals to make functions more effective were evaluated. The Cabinet of Ministers adopted results of the review after elections of the Parliament on 5 February 2019. In fiscal terms, efficiency gains of EUR 51,3 million for 2019 were achieved, which provided additional funds for reprioritising expenditures both within line ministries and also for general government priorities - EUR 7,7 million were allocated for government priorities, and EUR 43,6 million were identified as internal ministerial resources, thus 
illustrating the increase in the internal reallocations of the resources and prioritization within the line ministries.

For the scope for spending review 2019, horizontal review of the state budget programme expenditure (improvement of the centralised purchasing of goods and services; more economical and rational implementation of the functions funded by the state budget; mitigation of the administrative burden (also municipalities); implementation of the principle of "zero-based budgeting" for specific budget programmes/subprograms); review of the sector policy funding (health sector assessment by reviewing the effectiveness of inpatient healthcare funding; analysis of Ministry of Education and Science supervised areas (higher education, student loans, general education, school system); review of the allocated funding for priority measures; efficiency and improvement of the performance of sector functions) were done. As a part of the strategic review some legislative measures on process and system improvements were taken.

In 2019 based on Canada's experience for spending reviews, a strategic review form for national budget programmes/sub-programmes was introduced. In fiscal terms, efficiency gains of EUR 93,7 million for 2019 were achieved, which provided additional funds for reprioritizing expenditures both within line ministries and also for general government priorities.

The most notable achievements of the spending review during these years are as follows.

- In 2016 - comprehensive spending review, review of all budget expenditure. As a result, "scorecards" were introduced showing the link between resources and policy goals. It helps to understand how much resources (financial and human) have been invested and what are the main benefits for society. An Interactive Budget Infographic has been created, which allows the user to familiarize himself with nine areas of the budget (e.g. health, education, social security) and the funding allocated to them, as well as get to know detailed information on investment directions in each sector and funding source. Visualized budgets of the ministries and other central government institutions where the user can get to know about the areas of activity, allocated funding and the main benefits for the society were created. To ensure the transparency of the health care budget, changes have been made in the structure of the budget programs of the Ministry of Health.

- In 2017 jointly with sector and Bank of Latvia experts, a zero-based budgeting pilot project was prepared for the reimbursed pharmaceuticals. In addition, several regulatory enactments have also been amended, thus reducing the administrative burden on ministries and replacing technical activities with analytical ones. An evaluation of the state budget institutions in the field of public service delivery and ICT areas were made.

- In 2018 evaluation of real estate used for the needs of ministries, their subordinate state budget institutions and other central state budget institutions and their management expenses were done. Proposals for the state budget institutions' information and communication technology expenditure optimization were prepared by working group in cooperation with the Ministry of Environmental Protection and Regional Development.

- 2019 annual spending review was structured into three main areas: revision of the sector policies, revision of the state budget programs, and improvement of processes and systems. In the revision of the sector policies, significant emphasis was on the expenditure areas of the Ministry of Health and the Ministry of Education.

- During the analysed period, the role of strategic review with evaluation of achieved results and allocated resources is increasing as well as the reallocation of the resources within ministries 
(sectors) is increasing. The spending reviews have information base which contains historical data of performance indicators and resources granted for priority expenditures, as well as different sections. Expert working groups' conclusions and suggestions also form knowledge base for identification of savings options and reallocation decisions.

\section{Conclusions, proposals, recommendations}

1) Spending review is an essential part of public sector budgeting, ensuring reallocation of the resources and efficiency of public spending. Law on budget and finance management provides an obligation to conduct the review, but there are no clear procedures and also provisions for obtaining the information for the review.

2) Medium-Term and Comprehensive Spending Review is a significant step forward from the annual incrementalism of the past. Medium-term orientation and a meaningful discussion of long-term objectives for spending are crucial, and it allows much more focus on delivery and spend-to-save reforms through which a line-ministry can invest in changes in the first year to produce savings in next years.

3) The setting of the total public spending envelope for the review at the beginning of the budget process allows connecting annual budget planning with spring forecasts because the total level of expenditure is driven by 'top-down' macroeconomic considerations around what was affordable within fiscal rules.

4) Choosing the performance targets for annual and medium-term review and setting multi-year budgets and outcome targets for public spending through a spending review is a useful tool to improve efficiency and drive performance - but only if they are politically led. Line ministers and civil servants are engaged in the spending review process, and this led to the improvement of efficiency and performance for specific sectors.

\section{Bibliography}

1. Agasisti, T., Arena, M., Catalano, G., Erbacci, A. (2015). Defining Spending Reviews: a Proposal for a Taxonomy, with Applications to Italy and the UK. Public Money \& Management, 35(6), pp. 423-430.

2. Arena, M., \& Arnaboldi, M. (2013). Debate: Dealing with Spending Reviews-Italy. Public Money \& Management, 33(1), pp. 4-6.

3. Badovskis, M., Briede, J., Danovskis, E. (2017). Public Law. In "The Law of the Baltic States" Springer, Cham. (pp. 191-275).

4. Bogacheva, O., Smorodinov, O. (2018). Features of Spending Reviews in Ireland: Experience for Russia, Financial Journal, (5), pp. 34-45. doi: 10.31107/2075-1990-2018-5-34-45.

5. Bogachyova O., Smorodinov O. (2019). Spending Reviews: Experience of OECD Countries and Prospects for Russia. World Economy and International Relations, vol. 63 (3), pp. 59-67. doi.org/10.20542/0131-22272019-63-3-59-67.

6. Bourgon, J. (2009). Program Review. The Government of Canada's Experiences Eliminating the Deficit, 19941999 Centre for International Governance Innovation. Retrieved: https://www.cigionline.org/sites/default/files/the_government_of_canada_s_experience_eliminating_the_de ficit_1994-99.pdf Access: 10.01.2020

7. de Geus, A., Kraan, D.-J. (2012). The Dutch Fiscal Consolidation Package in a Comparative Perspective, OECD Journal on Budgeting, Vol. 12/1. http://dx.doi.org/10.1787/budget-12-5k9czxkk13lr

8. Emmerson, C. (2019) the Outlook for the 2019 Spending Review. Retrieved: https://pdfs.semanticscholar.org/d150/a3571b7a3c22a28b7ddf7d08c69c4ec88929.pdf Access: 09.01.2020

9. European Commission (2018). Commission Staff Working Document "Spending review". Accompanying the document "Communication from The Commission to the European Parliament, The European Council, The Council, The European Economic and Social Committee and the Committee of the Regions a Modern Budget for a Union that Protects, Empowers and Defends. The Multiannual Financial Framework for 2021-2027" [COM(2018) $321 \quad$ final]. Retrieved: https://eur-lex.europa.eu/legalcontent/EN/TXT/?uri=CELEX:52018SC0171 Access: 26.02.2020

10. Ferry, L., Eckersley, P. (2011), Budgeting and Governing for Deficit Reduction in The UK Public Sector: Act One "The Comprehensive Spending Review". Journal of Finance and Management in Public Services, 10(1), 14-23. 
11. Kabel, D. (2010). Fiscal Consolidation in the Netherlands. Presentation to the Network of OECD Senior Budget Officials, Netherlands Ministry of Rinance. http://www.oecd.org/governance/budgeting/45422410.pdf Access: 10.03.2020

12. Kennedy, F., Howlin, J. (2017). Spending Reviews in Ireland - Learning From Experience, OECD Journal on Budgeting. OECD, 16(2), pp. 93-108. doi: 10.1787/budget-16-5jg30cchf0g0.

13. Kraan, D.J. (2011). Recommendations to Denmark for Strengthening the Expenditure Framework and the Spending Review Procedures. Presentation to 32nd OECD Senior Budget Officer Meeting, Luxembourg, 2011. Retrieved: http://search.oecd.org/gov/budgeting/48141206.pdf Access: 10.03.2020

14. Lapsley, I., Midwinter, A. (2010). The Modernization of the State: The Comprehensive Spending Review in the UK. Revue française d'administration publique, (4), pp. 821-835.

15. Law on Budget and Financial Management (1994). Retrieved: https://likumi.lv/ta/en/en/id/58057-on-budgetand-financial-management. Access: 16.02.2020

16. Lienert, I. (2013). The Legal Framework for Public Finances and Budget Systems. In The International Handbook of Public Financial Management. Palgrave Macmillan, London pp. 63-83

17. Marti, C. (2019). Performance Budgeting and Medium-Term Expenditure Frameworks: A Comparison in OECD Central Governments. Journal of Comparative Policy Analysis: Research and Practice, 21(4), pp. 313-331. doi:10.1080/13876988.2018.1526492.

18. Ministry of Finance (2020). Spending reviews. Retrieved: https://www.fm.gov.lv/en/s/budget/spending_review/ Assess: 01.03.2020

19. Monacelli, D., Pennisi, A. (2015). Spending Review: Una, Nessuna, Centomila. Economia Pubblica. FrancoAngeli Editore, (1), pp. 69-108. doi: 10.3280/EP2015-001004.

20. OECD (2011). Typology and Implementation of Spending Reviews. GOV/PGC/SBO(2011)9. Retrieved: http://www.oecd.org/officialdocuments/publicdisplaydocumentpdf/?cote=GOV/PGC/SBO(2011)9\&doclangua ge=en Access: 01.03.2020

21. OECD (2013). Spending Review. Paper delivered at the 34th Annual Meeting of OECD Senior Budget Officials. Paris: OECD, 3-4 June 2013. GOV/PGC/SBO(2013)6. Retrieved: https://www.oecd.org/officialdocuments/publicdisplaydocumentpdf/?cote=GOV/PGC/SBO(2013)6\&doclangu age $=$ en Access: 01.03.2020

22. Postula, M. (2017). Spending Reviews-a Tool to Support the Efficient Management of Public Funds, Journal of Management and Business Administration. Central Europe, 25(2), pp. 63-90. doi: 10.7206/jmba.ce.24507814.196.

23. Robinson, M. (2014). Spending Reviews. OECD Journal on Budgeting, 13(2), 81-122.

24. Robinson, M. (2018). The Role of Evaluation in Spending Review. Canadian Journal of Program Evaluation, 32(3).

25. van Nispen, F. K. (2016). Policy Analysis in Times of Austerity: A Cross-National Comparison of Spending Reviews. Journal of Comparative Policy Analysis: Research and Practice, 18(5), 479-501.

26. van Nispen, F., de Jong, M. (2017). Evidence-Based Budgetary Policy: Speaking Truth to Power? EUI Working Papers, SPS 2017/1. Retrieved: http://cadmus.eui.eu/ Access: 16.02.2020

27. Vandierendonck, C. (2014). Public Spending Reviews: Design, Conduct, Implementation. European Commission.

https://ec.europa.eu/economy_finance/publications/economic_paper/2014/pdf/ecp525_en.pdf

Retrieved: 16.02.2020 